\title{
Investigating the Semantic Development of Modal Markers: The Role of Context
}

\section{Tomaž Potočnik and Matej Hriberšek*}

\section{INTRODUCTION}

The variety of approaches in investigating the phenomena commonly subsumed under the term modality can at least partly be explained by the fact that modality, when compared to other grammatical categories, is quite tricky to pinpoint in any given sentence. One can illustrate this with an example:

1) Erasmus, Convivium Religiosum 1067-9: In utroque cornu prominet pensile cubiculum [...] unde spectare licet pomarium et aviculas nostras. 'In each of the two corners, there is a closed balcony $[. .$.$] where one may rest, and whence one can see the fruit garden$ and our little birds.'

When asked what the tense of the main verb prominet is, one responds without hesitation that it is in the present tense. This can immediately be proved morphologically with the expected ending for the $3^{\text {rd }}$ person singular of the 2 nd conjugation, -et. In terms of aspect, the subject, pensile cubiculum, is clearly expressed in the nominative, so this and the absence of any passive endings both show that one is dealing with an active sentence.

Let us proceed to the domain of modality. In 1), one can identify one modal marker, licet. What kind of modality does it express and how does one know this? These questions prove slightly more embarrassing, for, except for the choice of the verb, there is nothing tangible

* University College London, Gower Street, London, WC1E 6вт, tomaz.potocnik.19@ucl.ac.uk; Faculty of Arts, University of Ljubljana, Aškerčeva 2, 1000, Ljubljana; matej.hribersek@ff.uni-lj.si. 
to work with - there is nothing a priori modal about licet. Digging into the relatively young field of modality, one learns that licet can express two kinds of modality, deontic and epistemic. The deontic one requires a person or an entity permitting or enabling the state of affairs. In our case, a connection with such a participant cannot be established, one must, therefore, conclude that the modal marker $l i$ cet expresses epistemic modality - more precisely, that of possibility. Indeed, it does, as demonstrated by the translation, which employs the more obvious epistemic modal can.

A second example, from the same period, shows another use of licet:

2) Erasmus of Rotterdam, Apotheosis Capnionis 46-7:

Pompilius. Quid, si divinem? 'What if I try to guess?'

Brassicanus. Licet. 'Sure.'

The form licet in 2) has the value of a simple confirmation. Such use of licet is widely attested in the archaic period. Intuition tells us that the use is semantically related to the one in 1); pragmatically speaking, modality seems to have disappeared from licet in the exchange in 2). The two examples show that modality is not discernible from the form of the modal marker and, as 2) shows, even the presence of a known modal marker does not guarantee modality.

Modality, while somewhat marked in the verbal complex, is not expressed morphologically in the same way as other categories, such as tense and aspect. For a historical linguist, this has practical consequences. While one can establish a detailed history of the semantic and morphological development of such forms as suffixes, propositions, or adverbs, with all the intermediate stages - insofar as sufficient textual evidence exists - in the case of modal forms the matter is more complicated. From the synchronic perspective, as well as the diachronic one, one quickly observes that for expressing various modal meanings and nuances, few forms are available altogether. Moreover, beside the modal meanings, most of them, especially verbs, have a primary, concrete, pre-modal meaning. Compare the following:

3) Cicero, Fam. 3.5: Perpaucos dies, dum pecunia accipitur quae mihi ex publica permutatione debetur, commorabor. 'I shall stay there for a very few days to get in some money due to me on an exchequer bill of exchange.' 
4) Cicero, Fam. 2.3: Ad quae si es, ut debes, paratus [...]. 'If you are prepared for that, as you must be [...].'

Since the morphological analysis is of little help in investigating the synchronic variation and diachronic development of a morphologically stable form, one needs to devise a tool, a proxy, to first efficiently describe the modal markers for Latin, and secondly, to reconstruct their development over centuries for which the textual resources are available. This article aims to demonstrate that, for Latin, a close investigation of immediate context may at least partly fulfill that role.

Chapter 2 presents a summary of leading theoretical positions in the domain of modality and defines the term paths of modality. Chapter 3 presents a model for studying the role of context in semantic change. Chapter 4 applies it to one Latin modal construction and examines one possible so-called switch context. Chapter 5 presents the implications and potential of this method for future research.

\section{RESEARCH IN MODALITY AND LATIN MODALITY}

\section{Previous research}

Despite some earlier efforts, such as Lyons's, ${ }^{2}$ research on modality took off in the 198 os with $\mathrm{Palmer}^{3}$ in functional and typological linguistics and Kratzer ${ }^{4}$ in formal semantics. The reasons for this relatively late surge in interest are probably due to the unclear character of modality. Compared to other categories, such as tense and aspect, modality is much harder to delineate, and it is therefore frequently unclear what the object of investigation should be. Rather than as a category, it is perhaps more useful to imagine it as a conceptual domain. ${ }^{5}$

Among the studies on Latin modality, it is necessary to mention Bolkestein, ${ }^{6}$ who, in her thorough study, considers semantic and syntactic factors to explain differences in meaning in Latin expressions of necessity.

\footnotetext{
Lyons, Semantics.

3 Palmer, Mood and Modality.

4 Kratzer, "What 'Must' and 'Can' Must and Can Mean."

5 Narrog, Modality, Subjectivity, and Semantic Change, 1.

6 Bolkestein, Problems in the Description of Modal Verbs.
} 
In their critical study, Bybee, Perkins, and Pagliuca ${ }^{7}$ have proposed some diachronic paths of development of modal meanings, propelled by specific common mechanisms of change. More importantly, they adopted a viewpoint that served as a model for several researchers in recent decades and which is adopted for this article, namely that "generalizations are more effectively formulated as generalizations about paths of development than as generalizations about synchronic states."

Van der Auwera and Plungian' have outlined a semantic map, a geometric representation of cross-linguistically relevant synchronic and diachronic relations between various modal meanings and uses. Relying on some aspects of their work, Magni ${ }^{10}$ has, in the domain of Latin, focused on grammatical markers characterized by the richness of meaning and usage. In her works on modality, she further develops the claim by Bybee, Perkins, and Pagliuca ${ }^{11}$ that meanings and functions ascribed to modality and mood are better described in terms of diachronic sequences than synchronic realities. Her approach, essential for this article, is based on the hypothesis that 1) semantic development is predictable, and 2) multiple uses of forms are not randomly distributed but are associated and located along predictable pathways. ${ }^{12}$

Concerning modality, several researchers underline the importance of subjectivity. Traugott and Dasher ${ }^{13}$ were the first to treat the domain of subjectivity diachronically. More recently, Narrog ${ }^{14}$ provides a valuable synthesis of competing theories on modality and subjectivity and he proposes his model to study empirical data in the domain of modality and subjectivity. Fruyt, in her studies of grammaticalization in Latin, ${ }^{15}$ shows the importance of grammaticalization in the studies of modality.

There is, furthermore, an ongoing project at the University of Lausanne to provide a comprehensive diachronic study of Latin modality under the leadership of Francesca Dell'Oro. This article is partially inspired by said project.

Bybee, Perkins and Pagliuca, The Evolution of Grammar.

Ibid., 4 .

Van der Auwera and Plungian, "Modality's Semantic Map," 79-124.

Magni, "Mood and Modality."

See note 10.

Ibid., 265-66.

Traugott and Dasher, Regularity in Semantic Change.

4 Narrog, Modality, Subjectivity, and Semantic Change.

15 E.g., Fruyt, "Grammaticalization in Latin," 661-864. 


\section{What is modality?}

Modality is not as easily defined as tense and aspect. The term modality describes a broad conceptual domain whose implications and functions have been investigated in both logic and linguistics. From a linguistic point of view, modality affects all areas of grammar and interacts with other categories, such as negation, tense, and aspect. While, as shown in the introduction, it cannot be investigated on the level of morphology, it is usually ${ }^{16}$ marked - together with tense and aspect - somewhere in the verbal complex; ${ }^{17}$ in fact, it is closely related to these two categories in that all three are concerned with the event or situation that is reported by the utterance: tense is concerned with the time of the event; aspect is concerned with the internal temporal constituency of the event; and "modality is concerned with the status of the proposition, that describes the event." 18

According to one definition, espoused by some researchers for example, Bybee, Perkins, and Pagliuca ${ }^{19}$ based on Palmer ${ }^{20}$ and Lyons $^{21}$ - modal markers are the grammaticalization of a speaker's attitudes and opinions. It has, however, recently been shown, that the notions of modality reach far beyond this definition. Indeed, it may be impossible to come up with a succinct characterization of the notion of modality. ${ }^{22}$ Instead, it has been suggested that modality is best viewed as a set of diachronically related functions and that the real understanding of modality would only emerge from the study of these diachronic relations. ${ }^{23}$

Understood in Palmer's terms, the influences of modality do not relate only or even primarily to the verb, but to the whole sentence. Consequently, it is challenging to decide what to include in investigations of modality. Various notions have been proposed for the study and delimitation of the domain of modality: attitudes article, however, and the methodology it proposes, is mostly focused on the modality in the verbal complex.

17 Magni, "Mood and modality," 193.

18 Palmer, Mood and Modality, 1.

19 Bybee, Perkins and Pagliuca, The Evolution of Grammar, 176.

20 Palmer, Mood and Modality, 16.

21 Lyons, Semantics, 452.

22 Bybee, Perkins and Pagliuca, Evolution of Grammar, 176.

23 See Bybee, Perkins, and Pagliuca, The Evolution of Grammar, 176-242, Magni, "Mood and Modality," 193-275. 
and opinions of the speaker, subjectivity, factuality, speech acts, as well as "a group of concepts that include possibility, necessity, permission, obligation, ability, and volition." ${ }^{24}$

While little agreement exists regarding the definition of modality, a widely held view among linguists is that the notion of subjectivity is of central importance. ${ }^{25}$ From this, it follows that a participant's subjective attitude can be applied either to the event itself or the proposition describing it. This leads to the critical division between event modality and propositional modality. ${ }^{26}$ Compare the following examples:

5) Dokončati moraš domačo nalogo.

'To-finish must-2 ${ }^{\text {nd }}$ pers.sg. homework-acc.'

6) Zdaj mora biti že doma.

'Now must- $3^{\text {rd }}$ pers.sing. to-be already home.'

The same verb, morati 'to have to' is employed in two different ways, representing a fundamental distinction in the domain of modality: deontic and epistemic.

The usage in 5), known as deontic modality, may be defined in terms of "permission" and "obligation"; ${ }^{27}$ however, this characterization might be too narrow and not appropriate for all cases. In more general terms, it might be defined as "an indication of the degree of desirability for the state of affairs, expressed in the utterance, typically, but not necessarily, on behalf of the speaker." As the word "degree" indicates, the desirability should be seen as situated on the scale, ranging from absolute necessity through intermediate stages to lesser desirability and undesirability. ${ }^{28}$

The example 6), on the other hand, is a case of epistemic modality, where the speaker expresses the estimation as to what degree the state of affairs expressed in the utterance holds for the world. One is again dealing with a scale from absolute certainty that the state of affairs is factual through intermediate stages to the negative side, i.e., that the state of affairs is certainly not factual or is untrue. ${ }^{29}$

24 Magni, "Mood and Modality," 1-2.

25 See Magni, "Mood and Modality," 194, Narrog, Modality, Subjectivity, and Semantic Change.

26 Palmer, Mood and Modality, 7-8.

27 Cf. e.g., Palmer Mood and Modality, 96-7.

28 Nuyts, "The Modal Confusion," 9.

29 Ibid., 10. 


\section{Pathways of Modality}

The idea of pathways of modality emerges from the view mentioned above that modality is best studied as a series of diachronically related functions, first discussed by Bybee, Perkins, and Pagliuca. ${ }^{30}$ According to this view, every modal form can be viewed as situated in a chain, "one giving rise to another." 31 This approach is based on the hypothesis that semantic development is predictable, that multiple uses of a single form are "not randomly distributed but are associated and located along certain pathways that reflect the evolution of grammatical meanings." ${ }^{32}$ Although unidirectionality in semantic development and the related studies of grammaticalization are to some extent controversial, ${ }^{33}$ it is widely held in studies of modality that deontic meanings are more basic than epistemic ones, the latter as a general rule appearing later than the former. ${ }^{34}$ This hypothesis is crucial for the present article.

Let us consider the verb possum 'I can.' At the very beginning, it conveyed the simple idea of physical strength and capability, as illustrated by example 7):

7) Plautus, Truc. 812-13: Plus potest qui plus ualet. Vir erat, plus ualebat: uicit, quod petebat abstulit. 'He can do the most, who is the strongest. He was a man, he was the strongest: he prevailed, what he wanted, he took with him.'

Now compare the following example with 7):

8) Plautus, Bacch. 580: Comesse panem tris pedes latum potes. 'You can eat up a loaf three feet wide.'

Clearly, there is a difference between 7) and 8): possum in 8) represents not the physical might, but the ability to do something. Possum has undergone a semantic shift from the specific meaning

33 See e.g., Haspelmath, "Why is Grammaticalization Irreversible?" Ziegeler, "Redefining Unidirectionality," etc.

34 See Bybee, Perkins and Pagliuca, The Evolution of Grammar; Magni, "Modality's Semantic Maps," etc. 
towards a more general one. In other words, it has moved along the predictable pathway mentioned above. Consider now the following pair of examples:

9) Plaut., Amph. 1.1: Animum aduorte. Nunc licet mi libere quiduis loqui. 'Pay attention: now, I am permitted to say anything freely.'

10) Plaut. Amph. 1.3: Licet, prius tua opinione hic adero: bonum animum habe. 'Yes, I will be here earlier than you think. Cheer up.'

In the first case licet 'it is permitted' carries the meaning of permission; in the second, it means no more than 'ok then.' Example 10) is so far along the pathway of modality, that it has lost almost all original lexical meaning and has instead adopted a pragmatic function of confirmation.

In short, research in the development of modality has established lines of development of modal expressions, the so-called pathways of modality. All the modal expressions, such as licet 'it is permitted,' oportet 'it is necessary,' debeo 'I have to,' and possum 'I can' move along these lines, as their meaning shifts from a more specific to a more general one. They start from the so-called pre-modal stages, as in 7), and sometimes finish as grammaticalized expressions that have lost all traces of their original meaning, as in 10). It is now known that modal expressions across languages follow similar paths and follow the same kinds of rules.

\section{THE ROLE OF CONTEXT}

In the literature on language change, one can frequently observe descriptions of an original state $\mathrm{A}$, of a target state $\mathrm{B}$, and speculation about what has happened in between. The intermediate stages - or, to be more precise, the continuum between the two described states - frequently remain underrated. ${ }^{35}$ Granted, for many languages, primarily, if one studies their earlier stages, the data for this intervening period may only be missing. It is, therefore, all the more critical for the historically well-attested languages, Latin as a prime example, to fill that void. This article tries to identify one aspect of what happens on the way from A to B. 
As demonstrated by the examples 1) and 2) above, for a successful study of semantic development of modal verbs, it is necessary to find a way that will make the change in the meaning of a formally unchanging word observable in the written texts that have come down to us. Heine ${ }^{36}$ observes that there are cross-linguistically predictable contexts that encourage the semantic change to take place. He proposes three critical types of contexts that need to be distinguished. These are:

Bridging contexts. - These contexts are what in the literature since Grice $^{37}$ has been described as "inferences" or "implicatures." They trigger a mechanism that adds to the existing meaning another meaning, which offers a more plausible interpretation of the utterance concerned. While the target meaning is the most likely interpretation, the interpretation in terms of original meaning cannot be ruled out. A linguistic unit can be associated with one or more bridging contexts. Bridging contexts can give rise to conventional meanings, but not necessarily.

Switch contexts. - For a switch towards a new meaning, a bridging context is not enough. What is needed is a so-called switch context. Such contexts are incompatible with some salient property of the source meaning; an interpretation in terms of the source meaning is therefore ruled out. The target meaning is now the only possible interpretation. Meanings appearing in switch contexts have to be supported by a specific context (which is not the case for conventionalizations, see below).

Conventionalizations. - Most context-induced meanings remain precisely that. They have usually been described as inferences, contextual meanings, or pragmatic meanings. However, some of them may develop some frequency of use: they no longer need to be supported by a specific context. They become the "usual," "inherent," "normal" meanings. ${ }^{38}$ A conventionalized meaning has the following properties:

- it can be used in a new context, other than the bridging and switch contexts; 
- while in the switch context the target meaning is incompatible with the source meaning, conventionalized meanings can contradict it;

- this means that the source and the target meaning can co-occur side by side.

The above contexts, therefore, suggest a four-stage scenario: At stage I, there is a standard, source meaning. At stage II, specific contexts can give rise to another meaning, which is more likely than the source meaning. At stage III, a type of context which is incompatible with the source semantics appears. At the final stage, stage IV, the new meaning, triggered by the switch contexts, has developed a sufficient frequency to stand alone and to become the new usual meaning. The new meaning can co-exist with the source meaning. As the authors hope to demonstrate in the following chapter, Heine's four-stage model can be fruitfully applied to the investigations of Latin modality. ${ }^{39}$

\section{CASE STUDY: LICET}

The impersonal form licet

and its identified meanings and functions

Latin has a limited number of modal expressions. These are the verbs oportet 'it is necessary,' debeo 'I have to,' licet 'it is allowed, it is possible,' necesse est 'it is necessary,' possum 'I can'; some adverbs, such as libenter 'gladly,' quidem 'certainly'; adjectives in -bilis '-ble'; and even more limited nouns, such as necessitas 'necessity.' As mentioned above, the verbs often have a modal as well as a non-modal (or pre-modal) function, such as debeo in example 3). The exemplification below focuses on licet, which has developed from the premodal form liceo 'I make available.'

The Oxford Latin Dictionary distinguishes three functions of $l i$ cet, which can be summarized as follows:

- "It is permitted"; "one may";

- (as the reply to a request or command); "Yes, certainly, I will";

- (with the subjunctive, developing into conjunction); "although." rio are summarized according to Heine, "On the Role of Context in Grammaticalization," 84-6. 
Wiesthaler's Latin-Slovenian Dictionary lists these meanings:

- "It is permitted," "one may," "it is freely available to," "one can";

- "although," "if only," "suppose that."

For the present purposes, this article suggests distinguishing between two semantic meanings of licet: one of permission - deontic use - and one of possibility - epistemic use. There is a third use, which, while semantically related to the first two, has adopted another pragmatic function, that of confirmation. The distinctions between the semantic and the pragmatic level is essential, for it illustrates the fact that semantic labels assigned to licet - or, arguably, to any word - are to some extent arbitrary, as the analysis below shows. It may be said that semantic meaning is a more conservative side of the word's profile, whereas pragmatic functions show the actual usage and, as the analysis below hopes to show, reflect the ongoing semantic change.

Licet occurs in two syntactic patterns. The first is a one-place pattern, where the only slot is filled by a clause, which can be finite (a subjunctive clause, sometimes, but rarely, introduced by $u t$ ) or non-finite (accusativus cum infinitivo). The second is a pattern with two slots, which are filled by a nominal constituent in the dative case and an infinitival clause. ${ }^{40}$ Sometimes a third slot is present to express the permitting agent or circumstance, with the structure per + permitting agent (see example 15) below) or by the ablative case. The focus of this article is on this slot, to see whether some in Heine's words - switch contexts can be identified in connection to it.

\section{Permitting participant or circumstance}

This chapter aims to observe the variation in permitting participants of the licet verbal structure in selected examples from Plautus. It aspires to see whether a switch context that would propel the development of modal meanings forward can be identified. Magni observes that an epistemic reading is favored with less typical participants (non-agentive, non-human, non-individuate, inanimate). In other words, "if there is no actor whose relationship to the 
accomplishment of the state of affairs can be estimated by the speaker, we are out of event modality, and a shift toward propositional modality takes place." ${ }^{11}$

As this chapter attempts to show, one is dealing with a continuum going from more to less specific meanings: the element on the left tends to have a more event-oriented meaning, while the one on the right a more propositional one. In order to form a better picture of the intermediate stages, it might be useful to illustrate the event modality > propositional modality spectrum with two extreme examples.

11) Plautus, Cas. 2.8: Licetne amplecti te? 'May I hug you?'

Example 11) is a clear case of deontic possibility. With the verb $l i$ cet, the speaker in inquiring whether the state of affairs in which he wants to engage is permitted by the addressee. The scope of the utterance is an event, i.e., whether or not it will be fulfilled. The situation is not controlled by the speaker.

12) Plautus, Aul. 2.8: Deinde egomet mecum cogitare intervias occepi: festo die si quid prodegeris, profesto egere liceat, nisi peperceris. 'Then I began to think with myself upon the road, if you are guilty of any extravagance on a festive day, you may be wanting on a common day, unless you are saving. ${ }^{42}$

Example 12) is a case of epistemic possibility, where the speaker is making observations about the situation. The scope of the utterance is the proposition. Additionally, the state of affairs is in complete control of the speaker and it takes a specialist to see any trace of permission in the licet of 12).

Let us briefly examine the difference between 11) and 12). While it may not be evident at first sight, it becomes more apparent if one takes a closer look at the permitting agent. What is standing between the completion of the action and the speaker's desire in 11), is a person. Example 12), on the other hand, has no permitting agent to speak of. What enables the state of affairs concerned - "to be wanting on a normal day" - is "extravagance on festive days." This is an extreme case of Magni's less-prototy- 
pical participant: ${ }^{43}$ it is non-agentive, non-human, non-individuate, and inanimate - the opposite of the agent in 11). The state of affairs is in complete control of the speaker.

If one takes into account the findings regarding the permitting agent in examples 11) and 12) and accepts to call the latter epistemic and the former deontic, this squares off a space on the continuum of semantic change in which one can now examine some other examples and place them on the axis in relation to 11) and 12), and to each other.

13) Plautus, Cist. 2.1: Postremo, quando aequa lege pauperi cum divite non licet, perdam operam potius quam carebo filia. 'After all, since with strict justice, a poor person is not allowed to contend with a rich one, I will lose my labor rather than lose my daughter.' ${ }^{44}$

In 13), it is slightly more challenging to assign the sentence a deontic or an epistemic reading. The desired state of affairs, i.e., "for a poor person to contend with a rich one," is not allowed by laws and customs. The permitting agent is non-standard in that it is inanimate and that it is not a person. Nevertheless, laws and customs intuitively signify a reliable source of authority - usually stronger than any single person's (with obvious exceptions) - a fact which would favor a deontic reading. On the other hand, the speaker is expressing his judgment about the degree of the factuality of the proposition, a clear sign of an epistemic use. Concerning 13), a note is in order regarding the notion of animacy, mentioned in Magni ${ }^{45}$ as an indicator of a probable epistemic reading: while certainly less animate when compared to one's master, they do not necessarily seem to presuppose a more epistemic reading.

The following example introduces yet another ambiguous permitting agent. It is implicit but can be reasonably supposed.

14) Plautus, Men. 2.3: Prandium, ut iussisti, hic curatumst. ubi lubet, ire licet accubitum. 'The breakfast, as you ordered, is prepared here; when you please, you may go and take your place. ${ }^{36}$ 
The speaker, a slave, is informing her master that he may take his place. The state of affairs is to go lie down (note that, in ancient Greece, this was the customary position to take one's meal). What is permitting it? Surely a slave would not presume to allow her master anything in the narrow, authoritative, sense? The deontic sense is, therefore, out of the question. The permitting agent here is simply the fact that the breakfast is on the table - it is, as in 12), a circumstance, which invites an epistemic reading of licet. It follows that a standard agent, even a person, may not be a clear indicator of the deontic or epistemic usage of a modal marker.

What can one say about the examples 11)-14) so far in terms of their progression along the diachronic pathway of modality? If 11) expresses a deontic meaning and 12) an epistemic one, located some way further along the axis of modal development, one may reasonably imagine 13) on the right of 11), but still somewhere in the vicinity, for laws and customs are there to allow certain events or states of affairs to take place, or preventing them from happening. 14), on the other hand, is closer to the meaning expressed in 12), as licet in both cases indicates favorable circumstances for the state of affairs to take place, and not an authority.

As mentioned above, according to the commonly accepted hypothesis, epistemic meanings appear later on the diachronic axis than non-epistemic ones. If non-typical permitting participants, such as in 14), favor the epistemic interpretation of modal verbs, they might well constitute what Heine (2002) calls switch contexts. Let us try to confirm this hypothesis with another example from Plautus.

15) Plautus, Mer. 5.4: Evtychus. Redde illi. 'Let him have [sc. her].' Demipho. Sibi habeat, iam ut volt per me sibi habeat licet. 'Let him have [her] for himself, as he wishes, as far as I am concerned.'

The permitting agent is explicit. The state of affairs is for the third person, illi, to have the person in question. What stands between the now and the fulfillment of the desired state of affairs desired by Eutychus, is Demipho. One is still in the sphere of the deontic licet.

The best kind of proof that one has indeed identified a switch context for licet, would be a conventionalized epistemic meaning, which has, with the help of sufficient frequency of use, become an independent meaning. Such a meaning, one should remember, can freely appear alongside the meaning which precedes it on the diachronic axis. If the hypothesis holds, the appearance of both deontic and epistemic licet in the same period, indeed, in many cases, 
in the same comedy, would, to some extent, be proof in itself - it remains to be confirmed by a quantitative study. For now, however, let us confirm this with the third use of licet, which also frequently appears on the same pages as the other two.

16) Plautus, Cur. 1.1: Phaedromus. Tace, occultemus lumen et vocem. 'Silence, let us hide the light and our voices.'

Palinurus. Licet. 'Alright.'

From example 16) it is easy to see that this usage is semantically related to the previous two. Its pragmatic function, however, is different. If in the case of deontic meaning the purpose of an utterance is to inform or inquire whether some authority allows the state of affairs to take place and in the case of epistemic meaning to observe whether some state of affairs can take place, the purpose of this usage is to confirm - anything, as the following examples show:

17) Plautus, Amph. 1.3: Iuppiter. [...] Numquid vis?

'[...] Do you want anything?'

Alcmena. Etiam: ut actutum advenias.

'Yes, that you return immediately.'

Iuppier. Licet [...]. 'Will do [...].'

18) Plautus, Bac. 1.1: Bacchis. Quid si hoc potis est ut tu taceas, ego loquar? 'Suppose it would be better that I speak and you stay silent?' Soror. Lepide, licet. 'Sure, with pleasure.'

19) Plautus, Capt. 5.1: Philocrates. Edepol, Hegio, facis benigne. sed quaeso, hominem ut iubeas arcessi. 'My my, Hegio, you act kindly. But please, order that the man be summoned here.' Hegio. Licet. [...] 'Certainly. [...]'

Examples 16)-19) show that a third function exists independently alongside the other two. If epistemic meaning requires a specific context - that of a non-typical permitting participant - to be present, the confirmatory licet does not seem to need it. In all four cases, it is used as a reply to orders or suggestions of various intensity. The frequency of such usage in Plautus (17 out of the first 10o) suggests that, according to Heine's model, one might be witnessing a fully conventionalized or conventionalizing meaning. On the continuum, demarcated by the examples 11) and 12), these four 
examples would be situated on the right side of 12): not only is the permitting participant not expressed, but they also seem to have shed all modal meaning as well.

As the examples above show, observing the permitting participant can reveal important details about the stage of development of a modal marker. The examples above, selected from a hundred attestations of licet in Plautus, show that in the case of a standard permitting agent, the deontic usage is probable, although by no means a rule, as example 14) shows. Conversely, a non-standard permitting participant may favor the epistemic interpretation, but not necessarily, as in example 13). It certainly seems plausible that the ambiguities identified above may be seen as switch contexts, which, in the right circumstances - such as sufficient frequency of usage - may create new modal meanings. It would, therefore, be worth conducting a quantitative analysis with a sufficient sample to confirm this.

\section{IMPLICATIONS OF THE STUDY \\ OF THE DIACHRONIC DEVELOPMENT \\ OF MODAL FORMS AND WHAT TO DO NEXT}

The introduction has highlighted a common problem in historical semantics: how to trace the semantic development of an unchanging form through history. Chapter 2 has presented existing research on modality and the most commonly accepted theoretical framework. Chapter 3 has adopted Heine's model ${ }^{47}$ for studying the role of context in diachronic development to bridge the gap highlighted in chapter 1 . Chapter 4 has attempted to illustrate the value of this framework on the example of the modal form licet and to identify the possible switch context, which could lead to further development, provided the support of a high frequency of usage.

Even the small sample from Plautus used in the study has highlighted the importance of closer studies of modality. First of all, reading the older English translations of Plautus reveals deficiencies in translations, where an epistemic licet is translated to English with a deontic modal allow or permit. This leads to such translations as "you have caused me to be allowed to," where the more natural translation would be "you have enabled me," the permitting circumstance being an obstacle removed by the addressee of the utterance, and not some permission based on his or her authority. 
Secondly, it turns out that the Oxford Latin Dictionary contains no trace of the meaning of possibility for licet; Wiesthaler's Latin-Slovenian Dictionary does briefly mention it. This is serious - if such a significant proportion of attestations of licet in the archaic period is leaning towards epistemic, one may well suspect that in the classical period - in Cicero's extensive opus, for instance - the number will be even higher. In other words, statistical data may soon confirm that our standard definitions of licet and other modals may have to be somewhat modified if they are to represent the actual usage in antiquity.

As observed above, Latin, with its material spanning for more than two millennia, is an essential resource for the study of modality in general. It offers a possibility to conduct a close quantitative analysis of the usage of modal markers. The results could then be compared to similar studies in other well-attested languages, such as Ancient Greek, English, or German, and offer another perspective in fields, such as cross-linguistic studies of modality and language typology, as well as in Indo-European and Romance linguistics.

\section{BIBLIOGRAPHY}

Bolkestein, A. M. "Problems in the Description of Modal Verbs: An Investigation of Latin." Studies in Greek and Latin Linguistics 1. Assen: Van Gorcum, 1980 .

Bybee, Joan. "Mechanisms of Change in Grammaticization: The Role of Frequency." In The Handbook of Historical Linguistics, edited by Brian D. Joseph and Richard D. Janda, 602-23. London: Blackwell, 2003.

- Language, Usage and Cognition. Cambridge: Cambridge University Press, 2010.

- Revere Perkins, and William Pagliuca. The Evolution of Grammar: Tense, Aspect and Modality in the Languages of the World. Chicago: University of Chicago Press, 1994.

Glare, P.G.W. Oxford Latin Dictionary. London: Oxford University Press / Clarendon Press, 1968.

Haspelmath, Martin. "Why is Grammaticalization Irreversible?" Linguistics 37.6 (1999): 1043-68.

— . "On Directionality in Language Change with Particular Reference to Grammaticalization." In Up and Down the Cline: The Nature of Grammaticalization, edited by Olga Fischer, Muriel Norde, and Harry Perridon, 17-44. Amsterdam: John Benjamin, 2004. 
Heine, Bernd. "On the Role of Context in Grammaticalization." In New Reflections on Grammaticalization 2, edited by Ilse Wischer and Gabriele Diewald, 83-101. Amsterdam: John Benjamins, 2002.

Hopper, Paul J., and Elizabeth C. Traugott. Grammaticalization. Cambridge: Cambridge University Press, 1993.

Lyons, John. Semantics. Cambridge: Cambridge University Press, 1977.

Magni, Elisabetta. "Modality's Semantic Maps: An Investigation of Some Latin Modal Forms." In Latina Lingua! Proceedings of the Twelfth International Colloquium on Latin Linguistics (Bologna, 9-14 June 2003); Papers on Grammar 9.1, edited by Gualtiero Calboli, 325-36. Rome: Herder, 2005.

__ "Mood and Modality." In New Perspectives on Historical Latin Syntax 4: Trends in Linguistics, Studies and Monographs, edited by Philip Baldi and Pierluigi Cuzzolin, 193-275. Berlin, Mouton de Gruyter, 2010. Narrog, Heiko. Modality, Subjectivity, and Semantic Change. Oxford University Press, Oxford, 2012.

Nuyts, Jan. "The Modal Confusion: On Terminology and the Concepts Behind It." In Modality: Studies in Form and Function, edited by A. Klinge and H. Hoeg Muller, 5-38. London: Equinox, 2005.

Palmer, Frank. Mood and Modality. 2nd ed. Cambridge: Cambridge University Press, 2001.

Traugott, Elizabeth Closs, and Richard B. Dasher. Regularity in Semantic Change. Cambridge: Cambridge University Press, 2002.

Van der Auwera, Johan, and Vladimir A. Plungian. "Modality's Semantic Map.” In Linguistic Typology 2 (1998): 79-124.

Wiesthaler, Fran. Latinsko-slovenski slovar. Ljubljana: Kres, 1993-2007.

Ziegeler, Debra. "Redefining Unidirectionality: Is There Life after Modality?" In New Reflections on Grammaticalization 2, edited by Olga Fischer, Muriel Norde, and Harry Perridon. Amsterdam: John Benjamins, 2003. 


\section{ABSTRACT}

The article tackles the problem of studying diachronic semantic changes of modal markers in Latin. It proposes to do so by using context as a proxy for tracing the development of otherwise unchanging forms. In the first part, the leading theoretical positions in modality studies are presented, especially the notions of deontic modality, epistemic modality, and pathways of modality. In the second part, Heine's model for studying the role of context in language change is presented and applied to the modal verb licet. In the case study of licet, an attempt is made to identify the so-called switch context, which co-creates the conditions necessary for the semantic change.

KEYWORDS: modality, Latin modality, grammaticalization, deontic, epistemic

\section{RAZISKOVANJE SEMANTIČNEGA RAZVOJA PRI MODALNIH OZNAČEVALCIH: VLOGA KONTEKSTA}

\section{IZVLEČEK}

Članek obravnava raziskovanje diahronih semantičnih sprememb pri modalnih označevalcih v latinščini. Semantičnemu razvoju sicer nespremenljivih oblik sledi z opazovanjem konteksta. V prvem delu so predstavljena glavna teoretska stališča pri preučevanju modalnosti, zlasti pojmi deontične modalnosti, epistemične modalnosti in modalnih poti. $\mathrm{V}$ drugem delu je predstavljen Heinejev model za preučevanje konteksta pri jezikovnih spremembah. Model je ponazorjen na primeru modalnega glagola licet. Študija primera licet je poskus razpoznavanja takoimenovanega preklopnega konteksta, ki soustvarja pogoje, potrebne za semantično spremembo.

KLJUČNE BESEDE: modalnost, latinska modalnost, gramatikalizacija, deontičnost, epistemičnost 